\title{
Possible role of 18-kDa translocator protein (TSPO) in etifoxine-induced reduction of direct twitch responses in isolated rat nerve-skeletal muscle preparations
}

\author{
Plamen I Zagorchev', Vesela Yu Kokova*, Elisaveta G Apostolova ${ }^{2}$, Lyudmil P \\ Peychev $^{2}$ \\ ${ }^{1}$ Department of Medical Physics and Biophysics, ${ }^{2}$ Department of Pharmacology and Drug Toxicology, Faculty of Pharmacy, \\ Medical University-Plovdiv, Vasil Aprilov Str. 15A, 4000 Plovdiv, Bulgaria
}

*For correspondence: Email: vesela_uk@abv.bg; Tel: +35932 602099

Sent for review: 12 February 2018

Revised accepted: 15 June 2018

\begin{abstract}
Purpose: To determine the effects of etifoxine on directly-elicited twitch tension of isolated rat nerveskeletal muscle preparations and to propose a possible explanation of the mechanism of the observed effect.

Methods: Striated muscles contractile activity was elicited by electrical field stimulation. The effects of etifoxine and nifedipine on direct single twitch response were studied.

Results: The results demonstrate that the effect of etifoxine on skeletal muscle depends on the concentrations: low concentrations $\left(10^{-8} \mathrm{M}\right.$ and $\left.10^{-7} \mathrm{M}\right)$ have little effect on twitch tension, whereas higher concentrations $\left(10^{-6} \mathrm{M}\right.$ and $\left.10^{-5} \mathrm{M}\right)$ induced a significant decrease in the direct single twitch response in comparison to controls. The mean $I C_{50}$ (reduction of directly-elicited twitch tension) of etifoxine was $0.85 \times 10^{-6} \mathrm{M}$. The selective L-type calcium channel blocker nifedipine $\left(10^{-5} \mathrm{M}\right)$ induced a greater decrease in the muscle force than $10^{-6} \mathrm{M}$ etifoxine. The different abilities of etifoxine and nifedipine to reduce direct single twitch response may be related to their distinct mechanisms of action. The observed effect of etifoxine could be more complex. Probably etifoxine acts as a non-selective agent not only on L-type calcium channels Cav1.1 localized in sarcolemma but also on 18-kDa translocator protein (TSPO) in skeletal muscle.

Conclusion: Etifoxine-induced reduction of direct twitch responses could be attributed to an effect on TSPO and Cav1.1. Knowledge of the effects of TSPO ligands on the contraction of skeletal muscle might explain the role of TSPO in muscle contractility.
\end{abstract}

Keywords: Etifoxine, TSPO, Calcium channels, Direct single twitch response, Striated muscle

This is an Open Access article that uses a funding model which does not charge readers or their institutions for access and distributed under the terms of the Creative Commons Attribution License (http://creativecommons.org/licenses/by/4.0) and the Budapest Open Access Initiative (http://www.budapestopenaccessinitiative.org/read), which permit unrestricted use, distribution, and reproduction in any medium, provided the original work is properly credited.

Tropical Journal of Pharmaceutical Research is indexed by Science Citation Index (SciSearch), Scopus, International Pharmaceutical Abstract, Chemical Abstracts, Embase, Index Copernicus, EBSCO, African Index Medicus, JournalSeek, Journal Citation Reports/Science Edition, Directory of Open Access Journals (DOAJ), African Journal Online, Bioline International, Open-J-Gate and Pharmacy Abstracts

\section{INTRODUCTION}

Translocator protein (TSPO) is an $18-\mathrm{kDa}$ ubiquitous protein and its primary intracellular location is the outer mitochondrial membrane
[1,2]. The protein consists of a 169-amino acid sequence arranged as a five $a$-helical transmembrane structure [3]. Translocator protein is associated with some other proteins, e.g. the $32-\mathrm{kDa}$ voltage-dependent anion 
channel and the $30-\mathrm{kDa}$ adenine nucleotide transporter. These three proteins are part of the mitochondrial permeability transition pore (MPTP) [4]. Different mitochondrial functions has been related to TSPO, including cholesterol transport and steroidogenesis [5], mitochondrial respiration, MPTP opening, regulation of the mitochondrial membrane potential, regulation of the mitochondrial respiratory chain, apoptosis and cell proliferation [5-10].

Translocator protein is also expressed in various other locations, apart from mitochondria. For example, TSPO is located on the outer cell membrane and in the cell nucleus [4,11]. The research on TSPO located in areas other than the outer mitochondrial membrane would be interesting, because, until now, it receives little attention.

Translocator protein is expressed in many organs, although secretory and glandular tissues appear to contain higher amount of this protein [1]; intermediate levels of TSPO are observed in renal and myocardial tissues and lower levels are found in the brain and liver [1,12].

Translocator protein is active in many other functions such as brain damage as a result of the activation of microglia, effects on the immune system and the host-defense response related to the phagocytes, ischemia, inflammation, responses to stress, influence on voltagedependent calcium channels, involvement in cell growth and differentiation, and cancer cell proliferation [10].

Translocator protein is also expressed in skeletal muscle where high levels of TSPO mitochondrial RNA are recovered [12]. The protein has been detected in rat diaphragm $[13,14]$. High levels of TSPO were observed in the skeletal muscle of transgenic mice by immunohistochemical analysis [15]. It is supposed that TSPO plays a role in muscle contraction [16].

Etifoxine (ETX), a clinically approved drug for the treatment of anxiety disorders, has been identified as a synthetic TSPO ligand. The mechanism of action of ETX includes potentiation of $\mathrm{GABA}_{\mathrm{A}}$ receptor function in a direct allosteric manner, as well as by an indirect mechanism involving the activation of TSPO [17].

The aim of this study is to define the effects of the TSPO ligand etifoxine on directly-elicited twitch tension of isolated rat nerve-skeletal muscle preparations and to provide a possible explanation of the mechanism of the observed effect.

\section{EXPERIMENTAL}

\section{Animals, tissue preparations, and procedure}

The experiments were approved by the Bulgarian Food Safety Agency and the Ethics Committee of the Medical University of Plovdiv, Bulgaria (approval nos. 87/9.01.2014 and 5/29.09.2016, respectively). The study was performed in accordance with Basel Declaration [18] and ICLAS Ethical Guideline for Researchers [19].

Male Wistar rats weighing 160 - $200 \mathrm{~g}$ were euthanized by an overdose of ketamine 180 $\mathrm{mg} / \mathrm{kg}$ bw and xylazine $15 \mathrm{mg} / \mathrm{kg}$ bw and the transversus abdominis muscles were isolated. Preparations were obtained according to a previously described experimental protocol [20]. The muscle strips were immersed and isometrically fixed in individual organ baths containing $15 \mathrm{~mL}$ modified Krebs' solution maintained at 35,5 $\pm 0,3 \stackrel{\circ}{\mathrm{C}}$ and constantly aerated with $95 \% \mathrm{O}_{2}$ and $5 \% \mathrm{CO}_{2}$. The $\mathrm{pH}$ of the solution was kept at 7.28 \pm 0.08 . Preparations were put in the organ baths in a random manner.

Striated muscles contractile activity was elicited by electrical field stimulation (EFS). Two platinum electrodes were connected to an electronic stimulator (EFS - PZ03, C-optic, Bulgaria) and were placed on both sides of each strip. The initial muscle tension applied to achieve isometric recording was $7 \mathrm{mN}$.

In order to obtain a direct single twitch response, an electrical stimulus of $60 \mathrm{~V}$ supramaximal intensity, a frequency of $5 \mathrm{~Hz}$ and 500 us squarewave pulse duration was used. The duration of the muscle stimulation was $3 \mathrm{~s}$, followed by a $7 \mathrm{~s}$ pause. The mechanical responses produced by direct stimulation were recorded isometrically with a force transducer (TRI 201, LSi LETICA; Panlab S.L., Barcelona, Spain) and a computerbased system. This allowed the recording, archiving and statistical analysis of mechanical muscle activity as described previously [21]. The interval of discretization was 1 millisecond.

After an equilibration period of $20 \mathrm{~min}$, direct muscle stimulation was applied and the twitch contractions were recorded. This muscle activity was stable in the absence of any drug and was used as control twitch contraction activity. After this, nifedipine and etifoxine were added separately to the organ baths.

Seven concentrations of etifoxine $10^{-8}, 10^{-7}, 10^{-6}$, $3.10^{-6}, 5.10^{-6}, 7.10^{-6}$ and $10^{-5} \mathrm{M}$ were studied, and a concentration-effect curve was obtained. 
Initially, the lowest concentration was added and a five-minute record of the twitch contractions was registered. The strips were washed out with Krebs' solution (3 - 4 times) before adding a higher concentration of etifoxine.

Nifedipine was studied at a concentration of $10^{-5}$ $\mathrm{M}$.

The effects on the contractile activity of the drugs and their concentrations were evaluated about 25 min after their addition to the bath. In all experiments, direct muscle contractions were elicited by EFS applied 12 min after adding of 10 $5 \mathrm{M}$ pipecuronium to each organ bath. Pipecuronium induces a neuromuscular blockade and the presence of neuromuscular blocking agent excludes any possible indirect (nerve) stimulation of the muscle tissue.

The $I_{50}$ of ETX was calculated as the concentration of the drug required to produce 50 $\%$ reduction in the force of the muscle twitches (the control twitch contraction activity was taken as $100 \%)$.

The maximal duration of the experiments involving a single muscle strip was 45 min after the isolation.

\section{Drugs and solutions}

Etifoxine (Stresam ${ }^{\circledR}$, Biocodex, Gentilly, France) was suspended in $0.9 \%$ saline containing $0.1 \%$ Tween 20. Nifedipine was purchased from Sigma. The solution of pipecuronium was prepared using Arduan ${ }^{\circledR}$ (Gedeon Richter, Hungary), diluted in $0.9 \%$ saline.

The preparation solution had the following composition: $\mathrm{Na}^{+}(143 \mathrm{mmol} / \mathrm{L}), \mathrm{K}^{+} \quad(5.84$ $\mathrm{mmol} / \mathrm{L}), \mathrm{Ca}^{2+}$ (3.7 mmol/L) and $\mathrm{Cl}^{-}(157 \mathrm{mmol} / \mathrm{L})$.

Composition of Krebs' solution: $\mathrm{Na}^{+}-143$ $\mathrm{mmol} / \mathrm{L} ; \mathrm{K}^{+}-5.84 \mathrm{mmol} / \mathrm{L} ; \mathrm{Ca}^{2+}-2.5 \mathrm{mmol} / \mathrm{L}$; $\mathrm{Mg}^{2+}$ - $1.19 \mathrm{mmol} / \mathrm{L} ; \mathrm{Cl}^{-}$- $133 \mathrm{mmol} / \mathrm{L} ; \mathrm{HCO}_{3}^{-}-$ $16.7 \mathrm{mmol} / \mathrm{L} ; \mathrm{H}_{2} \mathrm{PO}_{4}{ }^{-}-1.2 \mathrm{mmol} / \mathrm{L}$ and glucose $11.5 \mathrm{mmol} / \mathrm{L}$.

\section{Statistical analysis}

All data are presented as mean \pm SEM. After verifying the normality of distribution by a Smirnov test, it was confirmed that all results were normally distributed. One-way analysis of variance (ANOVA), followed by Bonferroni Multiple Comparison Test and paired samples Ttest (with the aid of SPSS.17) were employed for statistical analysis. Differences were considered statistically significant at $p<0.05$.

\section{RESULTS}

Figure 1 represents the concentration-response curve (Hill curve) of etifoxine, fitted to the isometrically developed tension by means of a non-linear least mean square approximation.

The mean $I_{50}$ value of etifoxine-induced reduction of directly-elicited twitch tension was $0.85 \times 10^{-6} \mathrm{M}$ (Hill coefficient $\left.=1.15 ; n=15\right)$.

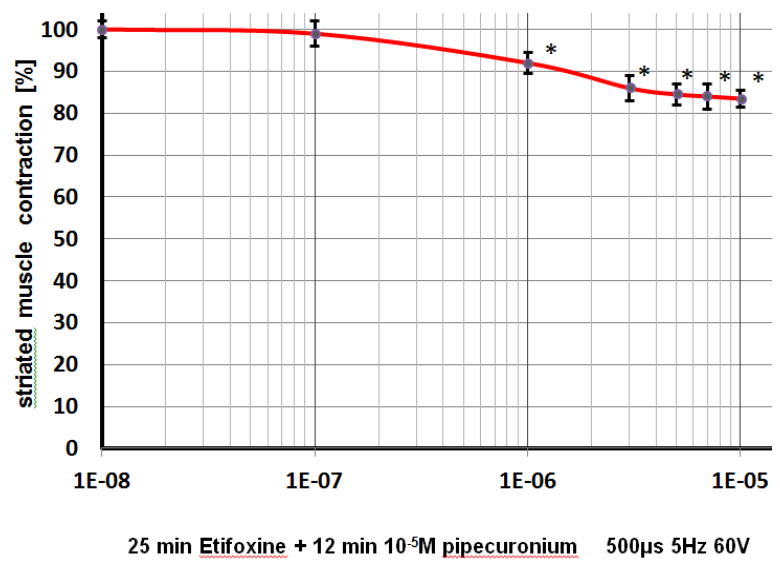

Figure 1: A concentration-response curve of $10^{-8} \mathrm{M} \div$ $10^{-5} \mathrm{M}$ etifoxine on the direct twitch responses of isolated rat abdominal striated muscle strips in the presence of $10^{-5} \mathrm{M}$ pipecuronium. Twitch responses were evoked at $5 \mathrm{~Hz}$; ${ }^{*} p<0.05$ vs controls (One-way analysis of variance); $\mathrm{n}=15$

Etifoxine (concentration range $10^{-8} \mathrm{M} \div 10^{-5} \mathrm{M}$ ) decreased the direct single twitch response in a concentration-dependent manner when $10^{-5} \mathrm{M}$ pipecuronium was present in the organ baths. Low concentrations of ETX $\left(10^{-8}\right.$ and $\left.10^{-7} \mathrm{M}\right)$ reduced the muscle contractions evoked directly, but no statistically significant difference was found. However, etifoxine at concentrations equal to and higher than $10^{-6} \mathrm{M}$ was more potent. In the presence of $10^{-5} \mathrm{M}$ pipecuronium, a statistically significant decrease of the direct single twitch response was observed at $10^{-6} \mathrm{M}$ etifoxine $(5.3 \pm 0.3 \mathrm{mN})$ and $10^{-5} \mathrm{M}(4.7 \pm 0.2$ $\mathrm{mN})$ in comparison to $10^{-8} \mathrm{M}$ etifoxine $(6.1 \pm 0.3$ $\mathrm{mN}), p<0.05$. Furthermore, the lowering of the muscle force was significantly greater with $10^{-6} \mathrm{M}$ than that obtained with $10^{-7} \mathrm{M}$ etifoxine $(5.3 \pm 0.3$ $\mathrm{mN}$ vs $5.8 \pm 0.3 \mathrm{mN}, p<0.05)$. The reduction of the direct twitch responses produced by $7.10^{-6} \mathrm{M}$ $(5.1 \pm 0.4 \mathrm{mN})$ and $10^{-5} \mathrm{M}(4.7 \pm 0.2 \mathrm{mN})$ etifoxine was significantly higher $(p<0.05)$ than when etifoxine at a concentration of $10^{-8} \mathrm{M}(6.1 \pm$ $0.3 \mathrm{mN})$ and $10^{-7} \mathrm{M}(5.8 \pm 0.3 \mathrm{mN})$ was employed (Figure 1). 

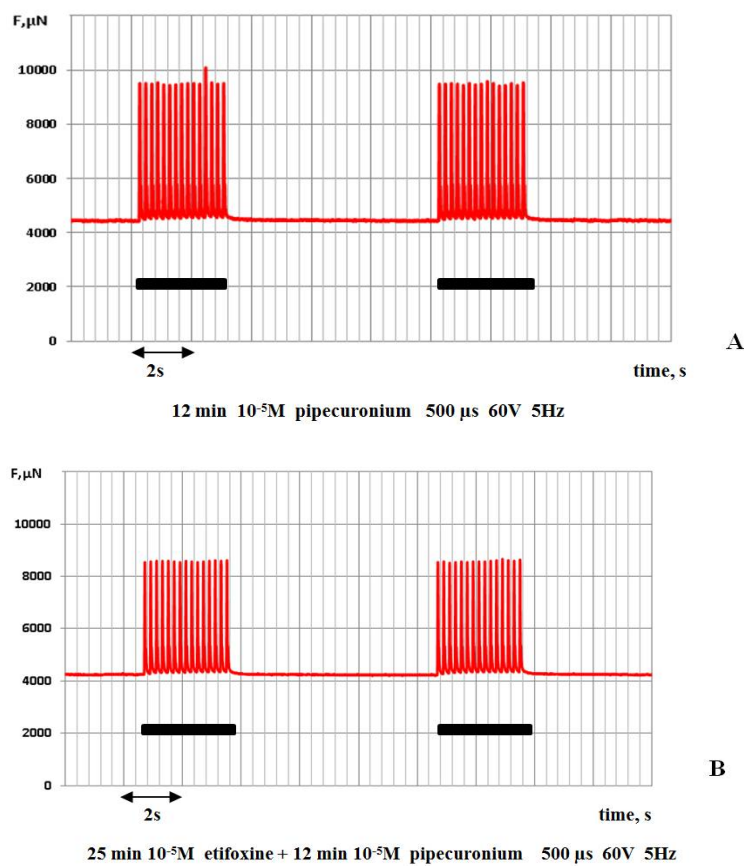

Figure 2: Effects of $10^{-5} \mathrm{M}$ pipecuronium alone $(\mathrm{A})$ and in combination with $10^{-5} \mathrm{M}$ etifoxine (B) on direct muscle twitch tension of isolated rat abdominal ( $\mathrm{n}$. intercostalis - $m$. transversus abdominis) preparations. The direct twitch tension was evoked at $5 \mathrm{~Hz}$ and the duration of the stimulus is marked by -

As shown in Figure 2, etifoxine $\left(10^{-5} \mathrm{M}\right)$ was added to the organ baths about 13 min before addition of pipecuronium $\left(10^{-5} \mathrm{M}\right)$. Etifoxine at a concentration of $10^{-5} \mathrm{M}$ evoked a significant reduction in the muscle force when compared to the controls (Figure 2).

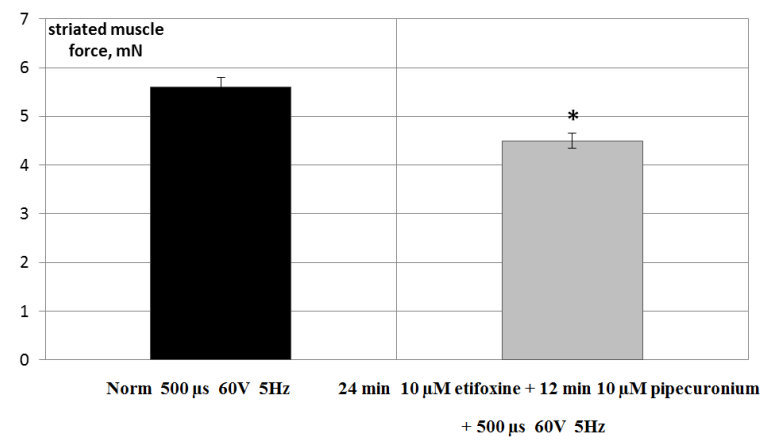

Figure 3: Effect of $10^{-5} \mathrm{M}$ etifoxine on directly-elicited twitch tension of isolated rat abdominal striated muscle strips in the presence of $10^{-5} \mathrm{M}$ pipecuronium. The direct twitch tension was evoked at $5 \mathrm{~Hz}$; ${ }^{*} p<0.05$ vs controls (paired T-test); $\mathrm{n}=9$

Etifoxine at a concentration of $10^{-5} \mathrm{M}$ in the presence of $10^{-5} \mathrm{M}$ pipecuronium had a significant effect on the directly-elicited twitch tension at $5 \mathrm{~Hz}$ and reduced the muscle force when compared to the controls $(p<0.05)$ (Figure 3).
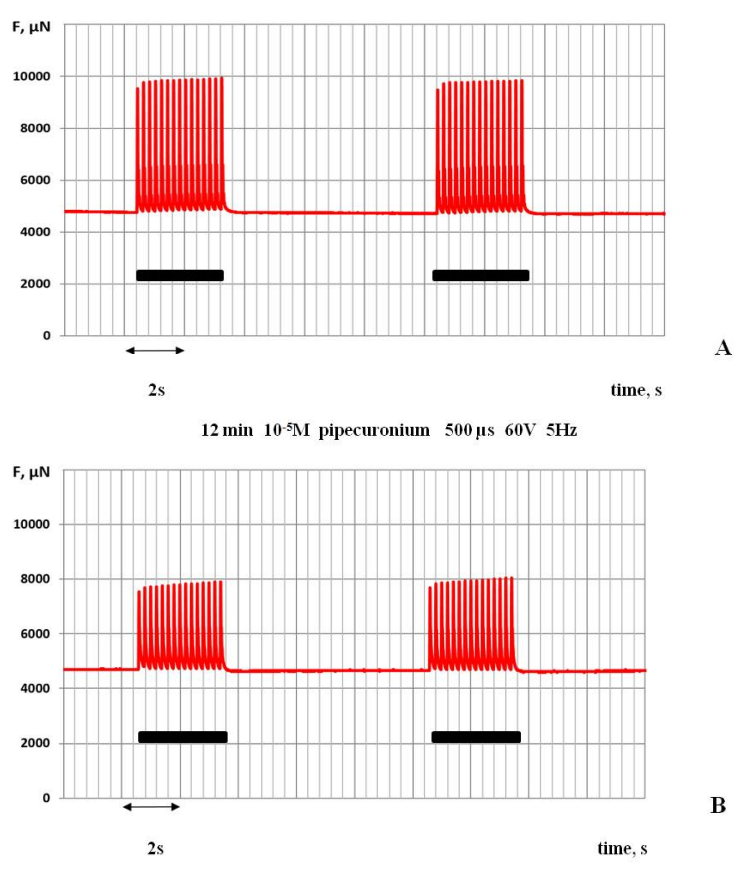

$25 \min 10^{5} \mathrm{M}$ nifedipine $+12 \min 10^{5} \mathrm{M}$ pipecuronium $500 \mu \mathrm{s} 60 \mathrm{~V} 5 \mathrm{~Hz}$

Figure 4: Effects of $10^{-5} \mathrm{M}$ pipecuronium alone $(\mathrm{A})$ and in combination with $10^{-5} \mathrm{M}$ nifedipine $(\mathrm{B})$ on the direct muscle twitch response of isolated rat abdominal ( $\mathrm{n}$. intercostalis - $m$. transversus abdominis) preparations. The frequency of the electrical stimulus was $5 \mathrm{~Hz}$ and the duration of the stimulus is marked by -

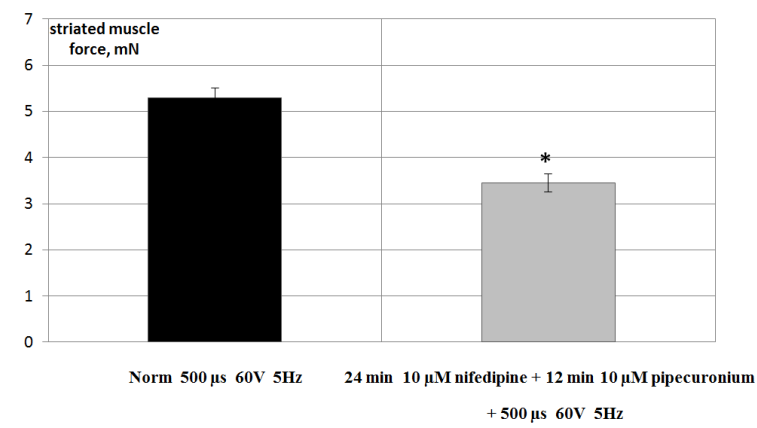

Figure 5: Effect of $10^{-5} \mathrm{M}$ nifedipine on directly-elicited twitch tension of isolated rat abdominal striated muscle strips in the presence of $10^{-5} \mathrm{M}$ pipecuronium. The direct twitch tension was evoked at $5 \mathrm{~Hz}$. ${ }^{*} p<0.05$ vs controls (paired T-test); $n=9$

Figure 4 shows the effect of $10^{-5} \mathrm{M}$ nifedipine on directly-elicited twitch tension. As expected, at this concentration nifedipine reduced the direct single twitch response significantly when compared to the control value in the presence of $10^{-5} \mathrm{M}$ pipecuronium $(3.5 \pm 1.2 \mathrm{mN}$ vs $5.8 \pm 1.2$ $\mathrm{mN}, p<0.05$ ) (Figure 5).

\section{DISCUSSION}

The results demonstrate that the effect of etifoxine on skeletal muscle was concentration 
dependent: low concentrations $\left(10^{-8}\right.$ and $\left.10^{-7} \mathrm{M}\right)$ ETX have little effect on twitch tension, whereas higher concentrations $\left(10^{-6}\right.$ and $\left.10^{-5} \mathrm{M}\right)$ induce a statistically significant decrease of the direct single twitch response in comparison to the controls. The observed effects of ETX may have been due to the blockade of L-type calcium channels by the drug and/or binding to TSPO in the skeletal muscle.

The first hypothesis is that etifoxine blocks the Ltype calcium channel, which leads to reduction in the force of the muscle twitches. To test this hypothesis, the effects of ETX were compared to these of nifedipine - a selective L-type calcium channel blocking agent.

The results show that nifedipine significantly reduces the direct single twitch response, suggesting a direct effect of the drug on skeletal muscle fiber (postjunctional action). The decrease in the directly elicited muscle contractions could be explained by the direct blockade of calcium channels in the skeletal muscle at the synaptic level.

The skeletal muscle contains calcium channels of the type $\mathrm{Ca}_{v} 1.1$ [22]. The $\mathrm{Ca}_{v} 1.1$ L-type calcium channels localized in the sarcolemma could be blocked by nifedipine. This process prevents calcium influx in the cytosol of the muscle cells and consequently reduces the muscle contraction. Nifedipine also acts as an antagonist of L-type calcium channels $\mathrm{Ca}_{v} 1.1$ localized in the transverse tubule membrane (aka DHPRs). However, the inhibition of DHPRs does not play a role in the reduced muscle contraction observed in presence of nifedipine.

The important structural and functional difference between the $\mathrm{Ca}^{2+}$ channel isoforms expressed in cardiac and skeletal muscle consists of a region that mediates the physical contact between DHPRs and ryanodine receptors (RyRs) in skeletal muscle.

Ryanodine receptors are a family of intracellular channels that play a role in the regulation of intracellular $\mathrm{Ca}^{2+}$ levels $[23,24]$ and exist as three mammalian isoforms: RyR1, RyR2, and RyR3. RyR1 is the major isoform expressed in skeletal muscle and RyR2 in cardiac muscle. Furthermore, all three isoforms are expressed in the brain [24]. RyR1 and RyR2 play a critical role in $\mathrm{Ca}^{2+}$ release during excitation-contraction coupling [24], but the importance of RyR3 in mammalian tissue is not yet fully understood. The three isoforms differ in their sensitivity to activation and inactivation by $\mathrm{Ca}^{2+}$.
RyR2 has the highest $\mathrm{Ca}^{2+}$ sensitivity $[23,25,26]$ with reference to its function in releasing $\mathrm{Ca}^{2+}$ from cardiac sarcoplasmic reticulum by $\mathrm{Ca}^{2+}$ induced $\mathrm{Ca}^{2+}$ release [25]. RyR1 is less sensitive to $\mathrm{Ca}^{2+}$ activation and inactivation since this isoform is coupled mechanically to L-type $\mathrm{Ca}^{2+}$ channels and it can be activated in the absence of extracellular $\mathrm{Ca}^{2+}$ [27]. RyR3 has the lowest $\mathrm{Ca}^{2+}$ sensitivity [26]. The mechanism of signal transduction between DHPR and RyR channels, which provides the coupling between the processes of excitation and contraction in the cardiac and skeletal muscle, is quite different [28].

In cardiac muscle, the depolarization of the cell membrane leads to opening of voltage-gated DHPR channel and subsequent $\mathrm{Ca}^{2+}$ influx. Thereafter $\mathrm{Ca}^{2+}$ binds to and activates the cardiac RyR2 isoform, which causes increased release of $\mathrm{Ca}^{2+}$ from the sarcoplasmic reticulum into the cytoplasm, i.e. calcium-induced calcium release occurs. In cardiac muscle, DHPRs are randomly located and while DHPR and RyR2 are in close proximity to each other. A direct association or direct functional interaction between the two proteins could not be found. In cardiac cells extracellular $\mathrm{Ca}^{2+}$ should be present to provide the interaction between DHPR and RyR2 [28,29].

In skeletal muscle, the depolarization of the muscle cell membrane leads to a conformational change in a voltage-gated DHPR channel, which allosterically activates the skeletal RyR1 isoform. Hence, skeletal muscle contraction is induced by mechanical, direct physical interaction between DHPR and RyR1 and a subsequent release of $\mathrm{Ca}^{2+}$ from the sarcoplasmic reticulum into the cytosol (mechanical coupling).

In skeletal muscle, DHPRs are grouped into tetrads (groups of four receptors) and each DHPR is located immediately above one of the RyR1 subunits. These tetrads represent the structural link between DHPR and RyR1 that allows $\mathrm{Ca}^{2+}$ independent excitation-contraction coupling in skeletal muscle $[28,29]$. Thus, the inhibition of L-type calcium channels $\mathrm{Ca}_{\mathrm{v}} 1.1$ localized in the sarcolemma, but not those localized in the transverse tubule membrane (DHPRs), is involved in the nifedipine-induced reduction of direct single twitch response.

The results show that, at equimolar concentration $\left(10^{-5} \mathrm{M}\right)$, nifedipine induces a greater decrease in the muscle force than etifoxine. It is possible that the different capacity of etifoxine and nifedipine to reduce direct single twitch response may be related to their distinct mechanisms of action. 
The evidence suggests that etifoxine acts in a different way compared to nifedipine, which is a selective L-type calcium channel blocker. Thus, the nature of the observed effect of etifoxine could be more complex. Probably etifoxine acts as a non-selective agent not only on L-type calcium channels $\mathrm{Ca}_{\mathrm{v}} 1.1$ localized in the sarcolemma but also on TSPO in skeletal muscle.

The second hypothesis regarding the influence of etifoxine on direct muscle contraction is the interaction with TSPO. Etifoxine activates the translocator protein 18-kDa (TSPO) [17]. Previous studies have shown that TSPO exists in the skeletal muscle [15], but its effect on the muscle contractility has not yet been fully explored.

Several studies have demonstrated that selective TSPO ligands significantly inhibit L-type $\mathrm{Ca}^{2+}$ channels in cardiac and vascular tissue $[30,31]$. Some potent and selective TSPO ligands interrupt the binding of $\left({ }^{3} \mathrm{H}\right)$ nitrendipine to L-type $\mathrm{Ca}^{2+}$ channels equally or even more effectively than the calcium antagonists verapamil and (+)cis-diltiazem. In functional studies, one of these compounds (7-acetoxy-6-(p-methoxyphenyl) pyrrolo $(2,1-d)-(1,5)$ benzothiazepine) shows selectivity for cardiac over vascular tissue.

This result represents a new implement about the role of TSPO in the cardiac function. Moreover, revealing the relationship between the chemical structure and the binding to TSPO and L-type $\mathrm{Ca}^{2+}$ channels could result in the synthesis of a new class of calcium channel blocking agents selective for cardiac tissue, with no affinity for TSPO [31].

The decrease in the muscle force observed in presence of etifoxine could not be explained only by influence on the calcium channels. It is possible that the reason for the reported difference in the effectiveness of etifoxine and nifedipine in reducing direct single twitch response is the further interaction of etifoxine with TSPO.

\section{CONCLUSION}

Etifoxine-induced reduction of direct twitch responses may be attributed to an effect on TSPO and L-type calcium channels $\mathrm{Ca}_{\mathrm{v}} 1.1$ localized in the sarcolemma. Further experiments should be carried out to test this hypothesis. An understanding of the effects of TSPO ligands on the contraction of skeletal muscle would provide an understanding of the role of TSPO in muscle contractility.

\section{DECLARATIONS}

\section{Acknowledgement}

This work was supported by a grant under Project № BG05M2OP001-2.009-0025, "Doctoral training at MU-Plovdiv for Competence, Creativity, Originality, Realization and Academism in Science and Technology - 2 (DOCTORANT - 2)", funded under the Operational Programme "Science and Education for Smart Growth", co-funded by Structural and Investment Funds of the EU.

\section{Conflict of interest}

No conflict of interest is associated with this work.

\section{Contribution of authors}

The authors declare that this work was done by the authors named in this article and all liabilities pertaining to claims relating to the content of this article will be borne by them. Plamen Zagorchev conceived and designed the study, collected and analyzed the data, participated in the writing of the manuscript. Vesela Kokova designed the study, collected and analyzed the data, performed the statistical analysis and wrote the manuscript. Elisaveta Apostolova participated in the study design, the data collection, the statistical analysis and the writing of the manuscript. Lyudmil Peychev participated in the study design, the statistical analysis and supervised the study. All authors read the article and approved the final version of the manuscript.

\section{REFERENCES}

1. Papadopoulos V, Baraldi M, Guilarte TR, Knudsen TB, Lacapere JJ, Lindemann $P$, Norenberg MD, Nutt $D$, Weizman A, Zhang MR, Gavish M. Translocator protein (18 kDa): new nomenclature for the peripheral-type benzodiazepine receptor based on its structure and molecular function. Trends Pharmacol Sci 2006; 27: 402-409.

2. Anholt RR, Pedersen PL, De Souza EB, Snyder SH. The peripheral-type benzodiazepine receptor. Localization to the mitochondrial outer membrane. J Biol Chem 1986; 261(2): 576-583.

3. Joseph-Liauzun $E$, Delmas $P$, Shire $D$, Ferrara $P$. Topological analysis of the peripheral benzodiazepine receptor in yeast mitochondrial membranes supports a five-transmembrane structure. J Biol Chem 1998; 273(4): 2146-2152. 
4. Scarf AM, Ittner $L M$, Kassiou M. The translocator protein (18 kDa): central nervous system disease and drug design. J Med Chem 2009; 52(3): 581-592.

5. Lacapere JJ, Papadopoulos V. Peripheral-type benzodiazepine receptor: structure and function of a cholesterol-binding protein in steroid and bile acid biosynthesis. Steroids 2003; 68: 569-585.

6. Casellas P, Galiegue S, Basile AS. Peripheral benzodiazepine receptors and mitochondrial function. Neurochem Int 2002; 40: 475-486.

7. Gavish M, Bachman I, Shoukrun R, Katz Y, Veenman L, Weisinger G, Weizman A. Enigma of the peripheral benzodiazepine receptor. Pharmacol Rev 1999; 51(4): 629-650.

8. Hirsch JD, Beyer CF, Malkowitz L, Beer B, Blume AJ. Mitochondrial benzodiazepine receptors mediate inhibition of mitochondrial respiratory control. Mol pharmacol 1989; 35(1): 157-163.

9. Corsi L, Geminiani E, Baraldi M. Peripheral benzodiazepine receptor (PBR) new insight in cell proliferation and cell differentiation review. Curr Clin Pharmacol 2008; 3: 38-45.

10. Veenman L, Papadopoulos V, Gavish M. Channel-like functions of the 18-kDa translocator protein (TSPO): regulation of apoptosis and steroidogenesis as part of the host-defense response. Curr Pharm Des 2007; 13 2385-2405.

11. Berkovich A, Ferrarese C, Cavaletti G, Alho H, Marzorati C, Bianchi G, Guidotti A, Costa E. Topology of two DBI receptors in human lymphocytes. Life Sci 1993; 52(15): 1265-1277.

12. Giatzakis C, Papadopoulos V. Differential utilization of the promoter of peripheral-type benzodiazepine receptor by steroidogenic versus nonsteroidogenic cell lines and the role of Sp1 and Sp3 in the regulation of basal activity. Endocrinol 2004; 145(3): 1113-1123.

13. Roeske WR, Yamamura HI. Identification and characterization of a novel benzodiazepine binding site in hearts, skeletal muscle and ileal muscle using the ligand (3H)Ro5-4864. Clin Res 1982; 30: 18 A.

14. Wilkinson M, Grovestine D, Hamilton JT. Flunitrazepam binding sites in rat diaphragm. Receptors for direct neuromuscular effects of benzodiazepines. Can J Physiol Pharmacol 1982; 60: 1003-1005.

15. Wang HJ, Fan J, Papadopoulos V. Translocator protein (Tspo) gene promoter-driven green fluorescent protein synthesis in transgenic mice: an in vivo model to study Tspo transcription. Cell Tissue Res 2012; 350(2): 26175.

16. Chiou LC, Chang CC. Pharmacological relevance of peripheral type benzodiazepine receptors on motor nerve and skeletal muscle. Br J Pharmacol 1994; 112(1): 257-261.

17. Schlichter R, Rybalchenko V, Poisbeau P, Verleye $M$, Gillardin J. Modulation of GABAergic synaptic transmission by the non-benzodiazepine anxiolytic etifoxine. Neuropharmacol 2000; 39: 1523-35.
18. The Basel Declaration [cited 2018 May 1]. Available from: http://www.basel-declaration.org/basel-declaration/

19. ICLAS Ethics and Animal Welfare Committee. ICLAS Ethical Guideline for Researchers [cited 2018 May 1]. Available from: http://iclas.org/committees/ethics-andanimal-welfare-committee

20. Zagorchev P, Apostolova E, Kokova V, Peychev L. Activation of KCNQ channels located on the skeletal muscle membrane by retigabine and its influence on the maximal muscle force in rat muscle strips. NaunynSchmiedeberg's Arch Pharmacol 2016; 389(4): 439-446.

21. Ivanov I, Nikolova S, Aladjov D, Stefanova I, Zagorchev $P$. Synthesis and contractile activity of substituted 1,2,3,4- tetrahydroisoquinolines. Molecules 2011; 16(8): 7019-7042.

22. Catterall WA, Perez-Reyes E, Snutch TP, Striessnig J. International Union of Pharmacology. XLVIII. Nomenclature and structure-function relationships of voltage-gated calcium channels. Pharmacol Rev 2005; 57(4): 411-425.

23. Coronado R, Morrissette J, Sukhareva M, Vaughan DM. Structure and function of ryanodine receptors. Am J Physiol 1994; 266: C1485 - C1504.

24. Franzini-Armstrong $C$, Protasi F. Ryanodine receptors of striated muscles: a complex channel capable of multiple interactions. Physiol Rev 1997; 77: 699-729.

25. Fabiato A. Calcium release in skinned cardiac cells: variations with species, tissues, and development. Fed Proc 1982; 41: 2238-2244.

26. Takeshima $H$, Yamazawa $T$, lkemoto $T$, Takekura $H$, Nishi M, Noda T, lino M. Ca2+-induced Ca2+ release in myocytes from dyspedic mice lacking the type-1 ryanodine receptor. EMBO J 1995; 14: 2999-3006.

27. Tanabe T, Beam KG, Powell JA, Numa S. Restoration of excitation-contraction coupling and slow calcium current in dysgenic muscle by dihydropyridine receptor complementary DNA. Nature 1988; 336: 134-139.

28. Leong $P$, MacLennan $D H$. Complex interactions between skeletal muscle ryanodine receptor and dihydropyridine receptor. Biochem Cell Biol 1998; 76: 681-694.

29. Protasi F. Structural interaction between RYRs and DHPRs in calcium release units of cardiac and skeletal muscle cells. Front Biosci 2002; 7: d650-658.

30. Bender AS, Hertz L. Pharmacological evidence that the non-neuronal diazepam binding site in primary cultures of glial cells is associated to calcium channel. Eur $J$ Pharmacol 1985; 110: 287-288.

31. Campiani G, Fiorini I, De Filippis M, Ciani S, Garofalo A, Nacci V, Giorgi G, Sega A, Botta M, Chiarini $A$ et al. Cardiovascular characterization of pyrrolo(2,1d) $(1,5)$ benzothiazepine derivatives binding selectively to the peripheral-type benzodiazepine receptor (PBR): from dual PBR affinity and calcium antagonist activity to novel and selective calcium entry blockers. $J$ Med Chem 1996; 39(15): 2922-2938. 